\title{
Application of tamarind pulp for wine production
}

\author{
Rafael Resende Maldonado ${ }^{\mathrm{a} *}{ }^{\circledR}$, Daniela Soares de Oliveira ${ }^{\mathrm{b}}{ }^{\oplus}$, Vanessa Dias Alves ${ }^{\mathrm{b}}$, \\ Elizama Aguiar Oliveira ${ }^{\circledR}$, Eliana Setsuko Kamimurad ${ }^{\circledR}$
}

a Universidade Estadual de Campinas, Brasil

b Faculdade Municipal Professor Franco Montoro, Brasil

c Universidade Estadual de Santa Cruz, Brasil

d Universidade de São Paulo, Brasil

*Autor correspondente (elizamaguiar@yahoo.com.br)

\section{N F O}

\section{Keyworks \\ tropical fruits \\ insoluble solids \\ pH \\ wine production}

\begin{abstract}
A B S T R A C T
Tamarind (Tamarindus indica L.) is a nutrient-rich fruit that has an acid and exotic flavor. It is widely consumed in natura at tropical countries such as India and Brazil. The aim of this study was to evaluate the application of tamarind as a substrate for the production of tamarind wine. The pulp from ripe fruits was used to produce wine in three different proceedings: (1) whole pulp, (2) pulp without insoluble solids and (3) pulp without insoluble solids and $\mathrm{pH}$ adjusted to 4.5 . In all cases, the fermentation was performed with Saccharomyces cerevisiae yeast and the initial concentration of soluble solids adjusted to $25^{\circ} \mathrm{Brix}$. The wine with the highest alcohol content $\left(10.2^{\circ} \mathrm{GL}\right)$ was obtained after 11 days of fermentation at room temperature $\left(\sim 25^{\circ} \mathrm{C}\right)$. The alcohol content increased in 2.5 times with the removal of insoluble solids, and the $\mathrm{pH}$ correction contributed to an additional increase of $10 \%$. The study demonstrated that tamarind presents good potential as a substrate for the production of wines, which can be an alternative to improve the utilization of the fruit.
\end{abstract}

\section{R E S U M O}

Aplicação de polpa de tamarindo para produção de vinho.

Tamarindo (Tamarindus indica L.) é uma fruta rica em nutrientes, ácida e de aroma exótico. Ela é comumente consumida na forma in natura em países tropicais como Índia e Brasil. O objetivo deste estudo foi avaliar a aplicação da tamarindo como substrato para produção de vinho de tamarindo. A polpa proveniente da fruta madura foi usada para produção de vinho em três tratamentos: (1) polpa integral, (2) polpa sem os sólidos insolúveis e (3) polpa sem sólidos insolúveis e com ajuste de pH para 4,5. Em todos os casos, a fermentação foi realizada com Saccharomyces cerevisae e com concentração inicial de sólidos solúveis ajustada para $25^{\circ}$ Brix. O vinho com maior teor alcoólico $(10,2$ $\left.{ }^{\circ} \mathrm{GL}\right)$ foi obtido após 11 dias de fermentação em temperatura ambiente $\left(\sim 25^{\circ} \mathrm{C}\right)$. O teor alcoólico foi 2,5 vezes maior para o tratamento polpa sem sólidos solúveis e o tratamento polpa sem sólidos solúveis e $\mathrm{pH}=4,5$ aumentou em mais $10 \%$ a produção de etanol. $\mathrm{O}$ estudo demonstrou que a tamarindo apresenta bom potencial como substrato para produção de vinhos, o que pode ser uma alternativa para aumentar a utilização da fruta. 


\section{INTRODUCTION}

The alcoholic fermentation of fruits is a process carried out with the consumption of fermentable sugars and, as a result, the production of mainly ethanol, carbonic gas and energy release. It is usually performed by yeasts, especially Saccharomyces genus (Allinger et al., 1978). The initial stage of the process is the preparation of the pulp: the fruits are washed, peeled, seeded and crushed. The concentration of soluble solids (SS) and the $\mathrm{pH}$ of pulp are adjusted if necessary, in order to make an ideal must for the yeast development. The SS is adjusted by the addition of saccharose. This process is called "chaptalization". The $\mathrm{pH}$ adjustment is performed with acid or basic solutions. In some cases, the removal of insoluble solids is necessary, as its presence may disturb the fermentative process (Aquarone, 2001).

Although grape is one of the most common fruit used for wine production, almost any fruit can be used to this purpose, resulting in different flavors and aromas. According to the Brazilian legislation, any fruit with the adequate content of fermentable sugars can be used to produce wine, as long as the variation is stated the name of the beverage (Brazil, 2004).

As a country with continental proportions and comprising different climates, Brazil is adequate for the cultivation of a great variety of fruits. Therefore, different products with particular flavors and aromas can be developed from fruits. Several studies are in progress in Brazil aiming to explore the production of wine from different fruits, such as sweetsop (Annona squamosa L.), seriguela (Spondias purpurea) and mangaba (Hancornia speciosa) (Muniz et al., 2002); jabuticaba (Myrciaria jaboticaba Berg) (Asquieri et al., 2004); strawberry (Fragaria moschata) (Andrade et al., 2013); carambola (Averrhoa carambola) (de Paula Valim et al., 2016) açaí (Euterpe oleracea) and cupuassu (Theobroma grandiflorum) (da Silva Pereira et al., 2014).

Tamarind tree (Tamarindus indica L.) is a plant of the dicotyledon group, and its fruit (tamarind) produces a very acid pulp which represents 30-50 $\%(\mathrm{~kg} / 100 \mathrm{~kg})$ of the ripe fruit. Due to the large amount of seeds in tamarind, the yield of the pulp is relatively lower when compared to the grape and other exotic fruits. Previous studies have indicated yield of red jambo (Syzygium malaccensis) pulp of approximately $75 \%(\mathrm{~kg} / 100 \mathrm{~kg})$ and grapes between 64 and $70 \%(\mathrm{~kg} / 100 \mathrm{~kg})$, depending on the type of treatment applied to extract the pulp. The pulp contains reducing sugars, pectin, protein, fibers, and cellulosic material. The main acid is the tartaric, with a concentration between $8-18 \%$ $(\mathrm{kg} / 100 \mathrm{~kg})$. Tamarind is used in curry-based sauces and in beverages and can be applied as an acidulant to sodas. Tamarind also has digestive and laxative effects besides hypolipidemic activity. India is the largest producer of tamarind, but the fruit is also consumed in the Northeast of Brazil, where it is usually gathered from native trees or trees grown on family farms (Augusta et al., 2010; Ferreira et al., 2011; Muzaffar \& Kumar, 2015; Paludo, 2015).

Although the fruit is largely consumed in natura or made into juice, there are relatively few studies in the literature about the use of tamarind as a raw material for the production of fermented beverages. In the study developed by Mbaeyi-Nwaoha \& Ajumobi (2015), tamarind was utilized associated with soursop (Annona muricata) in different proportions, and the results demonstrated that both fruits are good substrates for the production of table wines. However, that study was focused on the analysis of the nutritional composition of the wines.

Therefore, the aim of this study was to investigate the characteristics of the fermentation for the production of tamarind wine and evaluate the effects of $\mathrm{pH}$ and insoluble solids on the efficiency of the fermentation process.

\section{MATERIAL AND METHODS}

\section{Extraction and characterization of tamarind pulp}

Tamarind (Tamarindus indica L.) fruits were purchased in a local market in Campinas-SP-Brazil. The fruits were sanitized by immersion in water and a neutral detergent for 2 minutes and rinsed in running water. Subsequently, they were peeled manually and immersed in hot water $\left(80^{\circ} \mathrm{C}\right)$ for 5 minutes in order to favor the separation of the seeds from the pulp. The extraction of the pulp and its separation from the seeds were done manually, with a domestic sieve. The pulp obtained was frozen ($18^{\circ} \mathrm{C}$ ) in glass flasks for later characterization and fermentation.

In order to characterize the tamarind pulp, the mass of the whole fruits, the peeled fruits and the fruit pulp were weighed. The values obtained were used in order to calculate the extraction yield. The physicochemical analyses were conducted based on the methods of Adolfo Lutz Institute (IAL, 2005). The soluble solids $\left(\mathrm{SS},{ }^{\circ}\right.$ Brix $=\mathrm{kg} / 100 \mathrm{~kg}$ of glucose) were measured directly with a portable refractometer (Instrutemp). The insoluble solids (IS, \% $=\mathrm{kg} / 100 \mathrm{~kg}$ ) were measured by filtering a portion of pulp with a known mass in previously 
dried and weighed paper filter. The paper and the insoluble residues were dried in an oven $\left(105^{\circ} \mathrm{C}\right)$ until a constant weight was achieved and the IS were measured by the difference between the initial and final mass. The titratable acidity, expressed in tartaric acid (\% TA $=\mathrm{kg} / 100 \mathrm{~kg}$ of tartaric acid), was measured by the titration of the pulp with a standard solution of $\mathrm{NaOH}(0.1 \mathrm{~mol} / \mathrm{L})$ until a final $\mathrm{pH}$ between 7.8 and 8.2 was obtained. The $\mathrm{pH}$ was measured directly in a digital $\mathrm{pHmeter}$ (Digimed). The reducing sugars expressed in glucose $(\% \mathrm{RS}=$ $\mathrm{kg} / 100 \mathrm{~kg}$ ) were measured by titration of $10 \mathrm{~mL}$ of a standardized solution of reagent of Fehling and a solution of tamarind pulp. The vitamin $\mathrm{C}$ (vitC, $\mathrm{mg} / 100 \mathrm{~g}$ ) was measured by the titration of the pulp with a standardized solution of iodine $(0.1 \mathrm{~mol} / \mathrm{L})$ and a starch solution as an indicator. The ash content (\% Ash, $\mathrm{kg} / 100 \mathrm{~kg}$ ) was obtained by calcining a portion of pulp with a known mass in a muffle furnace at $550{ }^{\circ} \mathrm{C}$ for 3 hours. Ethanol was measured by densimetry. Samples of $100 \mathrm{~mL}$ of wine were distilled in simple distillation equipment until collecting $3 / 4$ of the initial volume in order to guarantee the entire distillation of ethanol present in the sample. The volume of the distillate was completed to $100 \mathrm{~mL}$ in a volumetric flask and the solution thus obtained was used to measure the density using a previously calibrated pycnometer. All analyzes were performed from samples collected directly from the liquid tamarind pulp obtained in this study. The analyzes were performed in triplicates and the results were expressed as the mean plus or minus the standard deviation.

\section{Production of tamarind wine}

The fermentation process for the production of tamarind wine were conducted in glass beakers with usable volume of $1.0 \mathrm{~L}$. In each fermentation set, the pulp was thawed, and the initial SS and the $\mathrm{pH}$ values were measured. The chaptalization (addition of sucrose) was performed in order to increase the SS value to $25^{\circ} \mathrm{Brix}(\mathrm{kg} / 100 \mathrm{~kg})$, thus achieving the desired alcoholic content which permits the fermented beverage to be classified as wine (4.0 a $\left.14.0{ }^{\circ} \mathrm{GL}=\mathrm{L} / 100 \mathrm{~L}\right)$ (Brazil, 2004).

The musts were inoculated with lyophilized Saccharomyces cerevisae (Fermentis ${ }^{\circledR}$ ). The reactivation of the yeasts was carried out according to the manufacturer instructions, which consists of spreading the yeasts in a volume of must equivalent to 10 times the yeast mass, at a temperature of $23 \pm$ $3^{\circ} \mathrm{C}$. Then the mixture is left to stand for 15 minutes, followed by slow stirring for 30 minutes until obtaining a cream consistency. The cream is inoculated into the must. Yeasts were inoculated at a concentration of $5.0 \mathrm{~g} / \mathrm{L}$.

The beakers were covered with plastic film with small holes to allow the elimination of the carbonic gas produced during the fermentation, and then, were incubated at room temperature $\left(\sim 25^{\circ} \mathrm{C}\right)$. The $\mathrm{SS}$ and $\mathrm{pH}$ were measured over the period of fermentation to evaluate the kinetics of the process.

The fermentations were carried out in three different conditions: (1) whole tamarind pulp, with $\mathrm{pH}=3.0$; (2) filtered tamarind pulp, i. e. without IS, with $\mathrm{pH}=3.0$; and (3) filtered tamarind pulp, with an adjusted $\mathrm{pH}$ of 4.5. All the tests were carried out in triplicate. The pulp was filtered with a cotton cloth (weight $210 \mathrm{~g} / \mathrm{m}^{2}$ ) for the removal of the IS. The $\mathrm{pH}$ adjustment was achieved by adding calcium carbonate $\left(\mathrm{CaCO}_{3}\right)$, until the $\mathrm{pH} 4.5$ (de Paula Valim et al., 2016).

\section{RESULTS AND DISCUSSION}

\section{Extraction and characterization of tamarind pulp}

From this extraction, the yield was calculated in two bases, the results were: $21.3 \%$ (kg pulp/100 kg of the whole fruit) and $31.2 \%$ (kg pulp/100 kg, excluding the mass of the peels). The last result is in accordance with the data observed in the literature (Ferreira et al., 2011; Muzaffar \& Kumar, 2015)

The results obtained in the characterization of tamarind pulp are presented in Table 1.

Table 1 - Physicochemical characterization of tamarind pulp.

\begin{tabular}{|c|c|}
\hline $\begin{array}{c}\text { SS }\left({ }^{\circ} \text { Brix }=\mathrm{kg} / 100 \mathrm{~kg} \text { of glucose }\right) \\
\text { IS }(\%, \mathrm{~kg} / 100 \mathrm{~kg}) \\
\text { TA }(\%, \mathrm{~kg} / 100 \mathrm{~kg} \text { of tartaric acid }) \\
\text { pH } \\
\text { RS }(\%, \mathrm{~kg} / 100 \mathrm{~kg} \text { of glucose })\end{array}$ & $\begin{array}{c}13.5 \pm 0.1 \\
2.0 \pm 0.1 \\
1.52 \pm 0.04 \\
3.0 \pm 0.1 \\
9.0 \pm 0.3\end{array}$ \\
\hline $\begin{array}{l}\text { Vitamin C }(\mathrm{mg} / 100 \mathrm{~g}) \\
\text { Ashes }(\% \mathrm{~kg} / 100 \mathrm{~kg})\end{array}$ & $\begin{array}{c}38.0 \pm 0.8 \\
0.19 \pm 0.03 \\
\end{array}$ \\
\hline
\end{tabular}


The fleshy pulp of the tamarind is strongly adhered to the seed. This characteristic, which makes the extraction difficult and requires variable amounts of water, combined with a large quantity of skin and seeds, explains the low yield of extraction in tamarinds. Furthermore, physical chemical characteristics of the tamarind pulps may vary considerably in function of the means by which the extraction was conducted.

With regard to the soluble solids (SS), Silva, Oliveira \& Jales (2010) found values ranging from 2.8 to $5.0 \% \mathrm{w} / \mathrm{w}$ in tamarind pulps obtained from different manufacturers. These values are considerably lower than that obtained in our study $(13.0 \% \mathrm{w} / \mathrm{w})$. On the other hand, the TACO table (2011) indicates a high concentration of carbohydrates $(72.5 \%, \mathrm{~kg} / 100 \mathrm{~kg})$ and fibers $(6.4$ $\%, \mathrm{~kg} / 100 \mathrm{~kg}$ ), and low concentration of humidity $(22 \%, \mathrm{~kg} / 100 \mathrm{~kg})$ for the tamarind in natura. These values are higher than the SS and IS found in our study, which indicate the influence of the addition of water during the process of pulp extraction. A different study has stated that the pulp of the ripe tamarind may represent 30 to $50 \%(\mathrm{~kg} / 100 \mathrm{~kg})$ of the fruit (Muzaffar \& Kumar, 2015), which is closer to the results of our study $(31.3 \% \mathrm{~kg} / 100 \mathrm{~kg}$ yield).

The tamarind is rich in vitamin C. A content of
$36.73 \mathrm{mg} / 100 \mathrm{~g}$ of vitamin $\mathrm{C}$ was found in the pulp (Silva et al., 2008), and values of 29.9 and 35.9 $\mathrm{mg} / 100 \mathrm{~g}$ in the pulp and wine, respectively (Mbaeyi-Nwaoha \& Ajumobi, 2015). These results are similar to those found in our study $(38.0 \mathrm{mg} / 100$ $\mathrm{g})$. The daily intake of vitamin $\mathrm{C}$ recommended for adults varies from 60 to $90 \mathrm{mg} /$ day (FAO, 2001), which means that approximately $200 \mathrm{~g}$ of tamarind pulp are sufficient to fulfill the daily needs of an adult.

Other data obtained in the physical chemical characterization indicate that most of the sugars present in tamarind pulp are reducing sugars $(9.0 \%$ of RS for $13.5^{\circ}$ Brix of SS, i.e. $66.7 \%$ of the sugars). Furthermore, one verified that the tamarind is a highly acid fruit, for the pulp obtained showed a low $\mathrm{pH}$ (3.1) and high titratable acidity (1.5\% $\mathrm{w} / \mathrm{w}$ of tartaric acid). Finally, the ash content obtained in our study was the same as that cited on the TACO table (2011).

\section{Tamarind wine production}

Figure 1 shows the results obtained from the first fermentation for the production of tamarind wine conduct with the whole pulp.

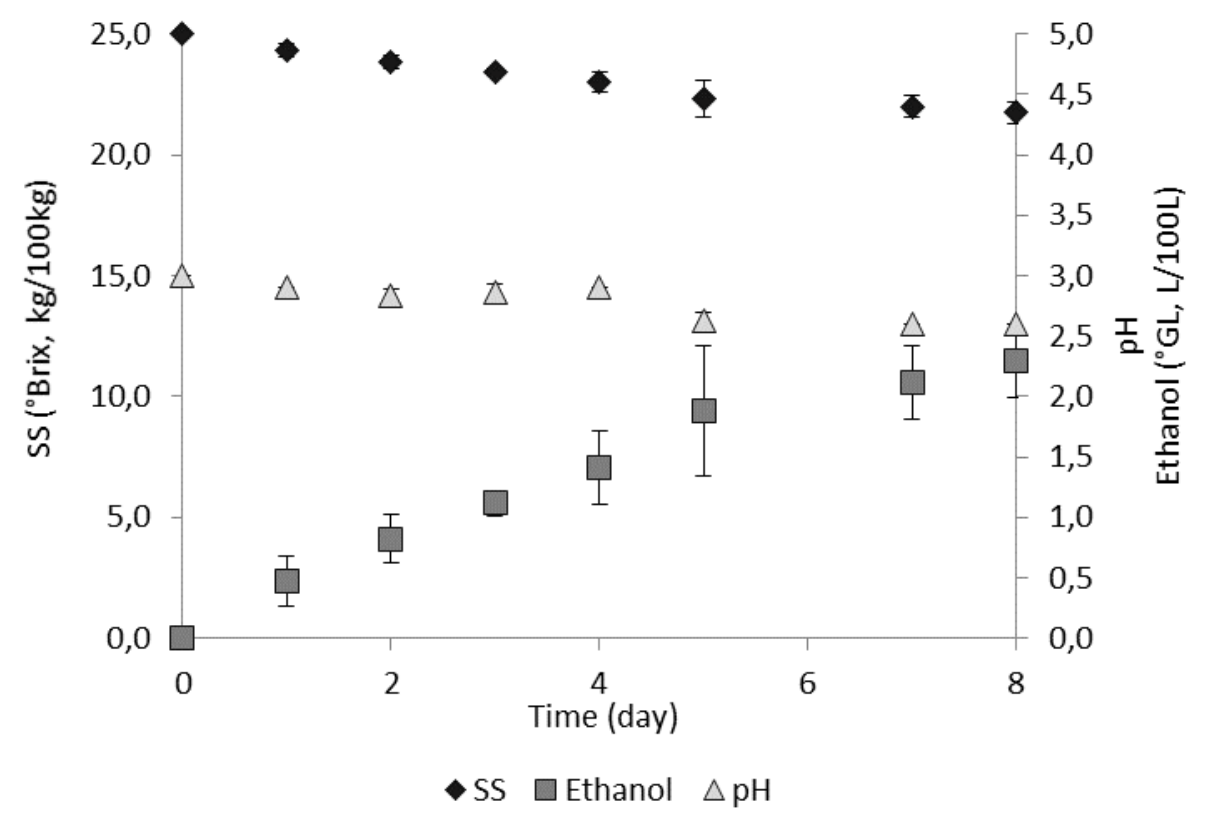

Figure 1 - Values of $\mathrm{pH}$ and concentration of soluble solids (SS, ${ }^{\circ}$ Brix) and ethanol $\left({ }^{\circ} \mathrm{GL}\right)$ of the alcoholic fermentation of the whole pulp of tamarind by S. cerevisiae at room temperature $\left(\sim 25^{\circ} \mathrm{C}\right)$.

These results indicate that the fermentation was not efficient, since there was a low consumption of $\mathrm{SS}$ and a small production of ethanol $(2.3 \pm 0.3$ $\left.{ }^{\circ} \mathrm{GL}, \mathrm{L} / 100 \mathrm{~L}\right)$ after 8 days of fermentation. The concentration of ethanol obtained did not allow the classification of the fermented beverage as wine according to the Brazilian legislation (Brazil, 2004). During the fermentation, a separation of the insoluble solids from the must occurred and, apparently, the yeasts were attached to the layer of insoluble 
solids that was formed on the surface of the must. Then, a second fermentation was conducted, in which a previous filtration of the must in a cotton cloth was done in order to remove the insoluble solids. The results can be seen in Figure 2 .

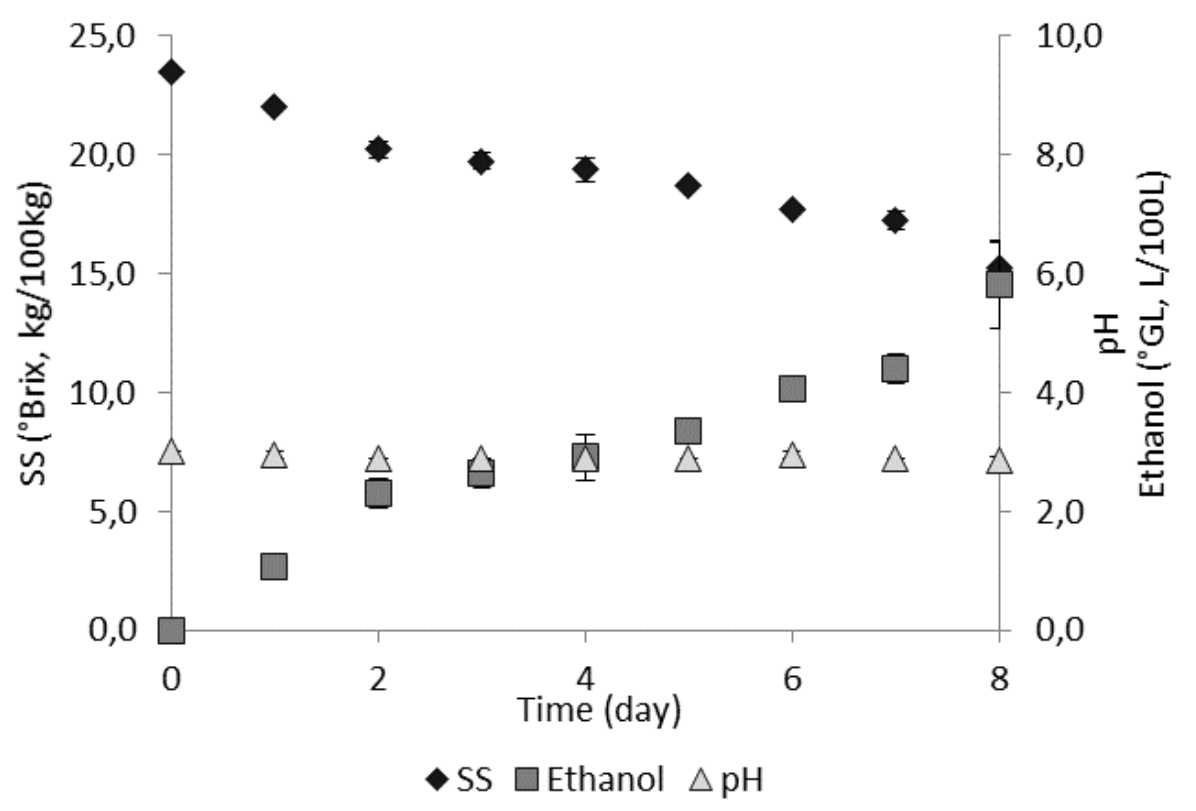

Figure 2 - Values of $\mathrm{pH}$, concentration of soluble solids (SS, ${ }^{\circ}$ Brix) and ethanol $\left({ }^{\circ} \mathrm{GL}\right)$ of the alcoholic fermentation of tamarind pulp (with the removal of insoluble solids but without initial $\mathrm{pH}$ adjustment) by $S$. cerevisiae at room temperature $\left(\sim 25^{\circ} \mathrm{C}\right)$.

The data presented in Figure 2 demonstrate that the removal of the insoluble solids improved significantly the performance of the alcoholic fermentation of tamarind pulp. Comparatively, the alcohol content in the second fermentation had reached 5.8 ${ }^{\circ} \mathrm{GL}$ after 8 days of fermentation (2.5 times higher than in the fermentation with the whole pulp). However, the alcohol content obtained after 8 days of fermentation was not sufficient for the fermented to be classified as a table wine, which must have between 8.6 and $14.0^{\circ} \mathrm{GL}$ (L/100 L) (Brazil, 2004). Thus, fermentation was prolonged until the alcohol content reached the desired range.

After 15 days of fermentation, the tamarind wine had reached $9.3 \pm 0.2^{\circ} \mathrm{GL}(\mathrm{L} / 100 \mathrm{~L})$, an adequate value for table wines. This value was higher than the alcohol content obtained in the production of tamarind and soursop wines, which was of 8.14 ${ }^{\circ} \mathrm{GL}(\mathrm{L} / 100 \mathrm{~L})$ after around five weeks of fermentation (Mbaeyi-Nwaoha \& Ajumobi, 2015). This means our experiment has a productivity 2.7 higher than what describe in literature. The obtained result was also similar to that observed in the production of carambola wine $\left(11.25{ }^{\circ} \mathrm{GL}\right)$, which used the same yeast strain (de Paula Valim et al., 2016). Those authors, however, obtained the fermentation in a shorter period ( 5 days) by applying optimized initial conditions of SS (23.8 o $\left.25.0^{\circ} \mathrm{Brix}\right), \mathrm{pH}(4.5$ to 5.0 ) and concentration of yeast (1.5 to $2.5 \mathrm{~g} / \mathrm{L}$ ).

The sequence of the study was conducted with the removal of insoluble solids by filtration, which proved itself to be effective in the second fermentation, and with the adjustment of the $\mathrm{pH}$ of the must to 4.5 (the most favorable condition to the yeast strain utilized) by the addition of calcium carbonate (de Paula Valim et al., 2016). The results of the fermentation with the $\mathrm{pH}$ correction and removal of insoluble solids are shown in Figure 3. 


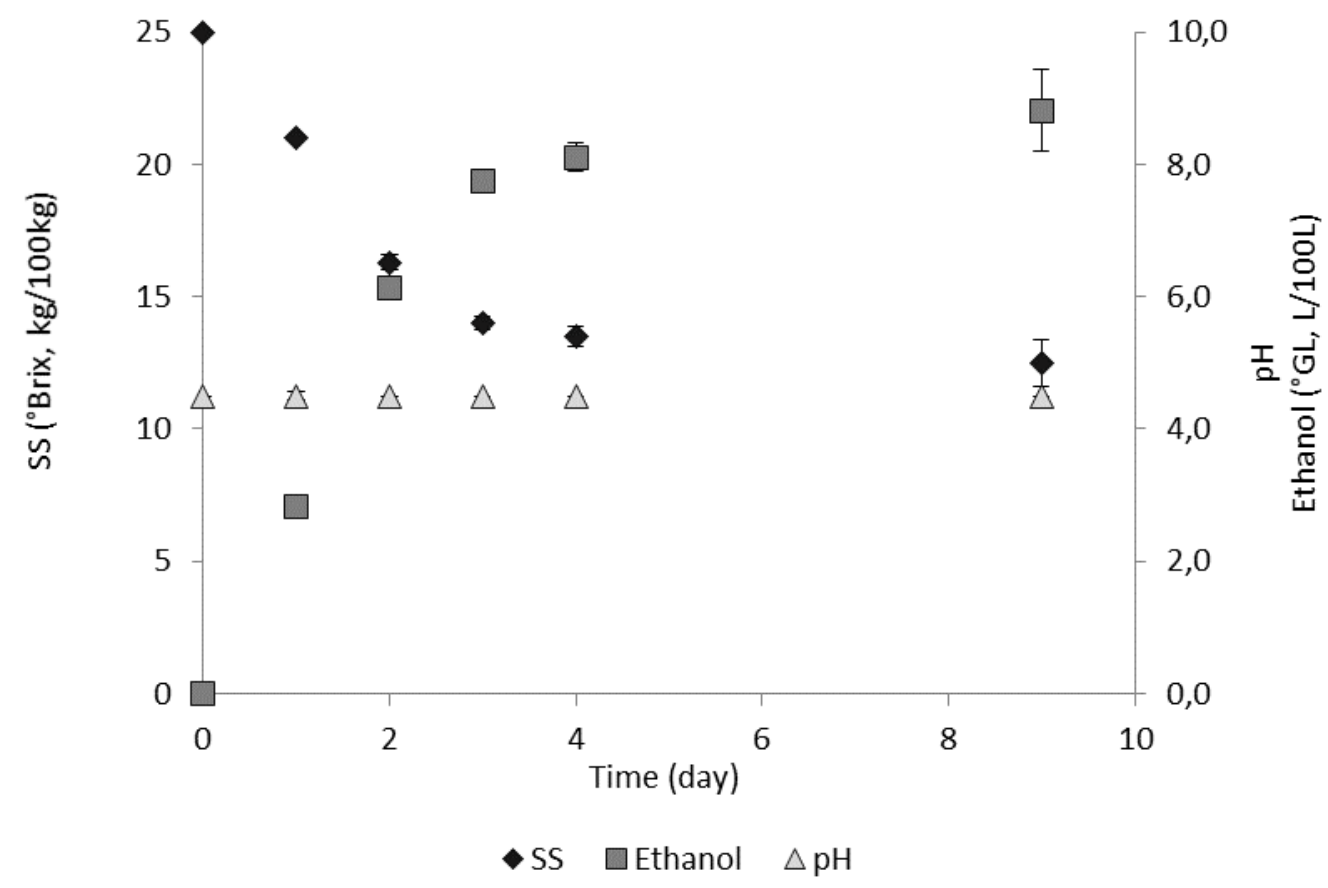

Figure 3 - Values of $\mathrm{pH}$, concentration of soluble solids (SS, $\left.{ }^{\circ} \mathrm{Brix}\right)$ and ethanol $\left({ }^{\circ} \mathrm{GL}\right)$ of the alcoholic fermentation of tamarind pulp (with the removal of insoluble solids and initial $\mathrm{pH}$ adjustment to 4.5) by $S$. cerevisiae at room temperature $\left(\sim 25^{\circ} \mathrm{C}\right)$.

The correction of the initial $\mathrm{pH}$ of tamarind pulp to 4.5 led to a greater efficiency of the fermentative process (Fig. 3). The consumption of SS and the production of ethanol on the first days of fermentation were accelerated noticeably, in contrast to the previous fermentations, in which the SS consumption was slow and gradual. The fermentation profile obtained was very similar to that observed for the production of carambola wine (de Paula Valim et al., 2016) using the same yeast strain and initial $\mathrm{pH}$, in which there was a tendency of stabilization of the fermentation process after 5 days. The fermentation in this third test was conducted up to 11 days of fermentation, reaching a final alcohol content of 10.2 $\pm 0.4^{\circ} \mathrm{GL}(\mathrm{L} / 100 \mathrm{~L})$. This result was approximately $10 \%$ higher than in the second fermentation $\left(9.3^{\circ} \mathrm{GL}\right)$, with a reduction of 4 days $(26.7 \%)$ in the fermentation period.

The three tests conducted in this study can also be compared in terms of the productivity of ethanol production, since the fermentation times were different. Considering the final ethanol productivity (calculated on the last day of each fermentation), the results obtained were $0.29,0.62$ and $0.93 \mathrm{~L}$ ethanol/(100 L wine. day), respectively. This means that removing IS increased productivity by 2.1 times (trial 2 versus trial 1 ) and that $\mathrm{pH}$ adjustment increased productivity by 1.5 times (trial 3 versus trial 2). It is also possible to make this comparison in terms of maximum productivity for each trial, which were, respectively, $0.47,1.15$ and 3.07 L ethanol/ (100 L wine. day). In this case, there was an increase of 2.4 times (trial 2 versus trial 1) and 2.7 times (trial 3 versus trial 2). This information demonstrates that the modifications undertaken in the study were efficient both to increase the total production of ethanol and to reduce the fermentation time.

The final alcohol content (in ${ }^{\circ} \mathrm{GL}, \mathrm{L} / 100 \mathrm{~L}$ ) achieved in the production of tamarind wine was also similar to the results obtained for other tropical fruits, as shown in the literature, such as of sweetsop (8.4), açaí and cupuassu (6.8), starfruit (11.1), seriguela (10.0), jackfruit (13.0), strawberry (9.6), mangaba (9.8) and tamarind (8.1) (de Paula Valim et al., 2016; Mbaeyi-Nwaoha \& Ajumobi, 2015; da Silva Pereira et al., 2014; Andrade et al., 2013; Asquieri et al., 2004; Muniz et al., 2002). This demonstrates that the tamarind, as well as other tropical fruits, shows good potential for the production of wines under adequate fermentation conditions.

\section{CONCLUSION}

This study demonstrated that tamarind is a good substrate for alcoholic fermentation and production of wine. The high concentration of insoluble solids (IS) and low $\mathrm{pH}$ are, however, limiting factors for the fermentation by the yeast used in the tests, 
which retard the process and lower the alcohol content. The utilization of the filtered pulp led to an increase in the alcohol content of 2.5 times. After removing IS, changing the initial $\mathrm{pH}$ from 3.0 to 4.5 promoted an increase of $10 \%$ in alcohol content, which reached $10.2^{\circ}$ GL. As the study was univariate, it is not possible to say whether there was an interaction between the two factors studied. The filtration and $\mathrm{pH}$ correction also enhanced the fermentation time, thus making the process more efficient. The results in this study are important due to the exiguous literature available dealing with the utilization of the tamarind in the production of processed foods and beverages.

\section{ACKNOWLEDGMENT}

Authors would like to thank Municipal College Professor Franco Montoro (Mogi Guaçu, SP, Brazil) and Technical College of Campinas (Campinas, SP, Brazil) for the technical support. For APM- Cotuca (Associação de Pais e Mestres of Technical College of Campinas) for the financial support. For all students of Nutrition and Food Technical courses that work in the different moments of this study.

\section{REFERENCES}

Alessio MV, Hoffmann PH, Carneiro, S M. Método rápido para extração de DNA de Puccinia kuehnii. Summa Phytopathologica, v.39, n.3, p.198- 200, 2013. https://doi.org/10.1590/S0100-54052013000300009

Allinger NL, Cava MP, Jongh DC, Johson CR, Libel NA, Stevens CL. Organic Chemistry. Rio de Janeiro: LTC Publisher Company, 656p. 1978.

Andrade MB, Perim GA, Santos TRT, Marques RG. Fermentação e caracterização de fermentado de morango. BBR- Biochemistry and Biotechnology Reports, v.2, p.265-268, $2013 . \quad$ doi: http://dx.doi.org/10.5433/23165200.2013v2n3espp265

Aquarone E. General information on alcoholic beverages. In: Aquarone E, Lima UA, Borzani W. Biotechnology - Food and beverages produced by fermentation. São Paulo: Edgard Blücher Publisher Company, pp.1-10, 2001.

Asquieri ER, Candido MA, Damiani C, Assis EM. Fabricación de vino blanco y tinto de jabuticaba (Myrciaria jaboticaba Berg) utilizando la pulpa y la cáscara respectivamente. Alimentaria, v.355, p.97-109, 2004.

Augusta IM, Resende JM, Borges SV, Maia MCA, Couto MAPG. 2010. Caracterização física e química da casca e polpa de jambo vermelho (Syzygium malaccensis (L.) Merryl \& Perry). Food Science and Technology, v.30, n.4, p.928-932.

Brazil. Brazilian Ministry of Agriculture, Livestock and Supply. Law n. 10970, 12 Sep 2004. http://www.agricultura.gov.br. Accessed on 02 Jan 2020. da Silva Pereira A, da Silva Costa RA, Landim LB, da Silva NMC, Reis MFT. Produção de fermentado alcoólico misto de polpa de açaí e cupuaçu: aspectos cinéticos, físico-químicos e sensoriais. Revista Brasileira de Tecnologia Agroindustrial, v. 8, p. 1216-1226, 2014.

de Paula Valim F, Aguiar-Oliveira E, Kamimura ES, Alves VD, Maldonado RR. Production of star fruit alcoholic fermented beverage. Indian Journal of Microbiology, v.56, p.476-481, 2016. https://doi: 10.1007/s12088-016-0601-9

FAO/OMS. Human Vitamin and Mineral Requirements. In: Report 7th Joint FAO/OMS Expert Consultation. Bangcoc, Thailand, 2001.

Ferreira RMA, Aroucha EMM, Góis VA, da Silva DK, de Sousa CMG. Sensorial quality of mixed jelly of watermelon and tamarind. Revista Caatinga, v.24, p.206, 2011.

IAL. Adolfo Lutz Institute. Analytical Standards of the Adolfo Lutz Institute. Imesp Publisher Company, São Paulo, BR, 2005. Accessed on 02 Jan 2020. http://www.ial.sp.gov.br

Mbaeyi-Nwaoha IE, Ajumobi CN. Production and microbial evaluation of table wine from tamarind (Tamarindus indica) and soursop (Annona muricata). Journal of Food Science and Technology, v.52, p.105-116, 2015. doi: https://doi.org/10.1007/s13197-013-0972-4

Muniz CR, Borges MDF, de Abreu FAP, Nassu RT, de Freitas CAS. Bebidas fermentadas de frutas tropicais. Boletim do Centro de Pesquisa de Processamento de Alimentos, v.20, p.309-322, 2002.

Muzaffar K, Kumar P. Parameter optimization for spray drying of tamarind pulp using response surface methodology. Powder Technology, v.279, p.179-184, 2015. doi: https://doi.org/10.1016/j.powtec.2015.04.010

Paludo N. Efeito de diferentes enzimas para extração de cor, compostos bioativos e rendimento de suco de uva. In: XXVII Salão de Iniciação Científica da UFRGS, Porto Alegre, 2015.

Silva ASA, Gurjão KD, Almeida FDC, Bruno RDLA, Pereira WE. Dehydration of tamarind pulp through the foam-mat drying method. Ciência e Agrotecnologia, v.32, p.18991905, 2008. doi: https://doi.org/10.1590/S141370542008000600032

Silva MTM, Oliveira JDS, Jales KA. Physico-chemical quality evaluation of frozen fruit pulps commercialized in the Ceará-Brazil. In: Congress Proceedings of V CONNEPI. Maceió, Alagoas, Brazil, 2010.

TACO. Brazilian Table of Food Composition (TACO). $4^{\text {th }}$ ed., NEPA-UNICAMP, Campinas, São Paulo, BR, 2011. Accessed on 02 Jan 2020. http://www.unicamp.br/nepa/taco/ 